\title{
Marketing Artificial Reef as Recreational SCUBA Diving Resources: Feasibility Study for Sustainable Tourism
}

\author{
Harriman Samuel Saragih \\ Business School - Management Department \\ Universitas Pelita Harapan \\ Tangerang, Indonesia \\ harriman.saragih@uph.edu
}

\begin{abstract}
Indonesia is known as a coastal country which has rich natural resources. Indonesia's islands have attracted scuba divers globally to dive and experience the sensation of Indonesia's maritime ecosystem. Previous studies have shown that scuba diving as an ecotourism object is able to contribute both positive and negative impact to the environment and the local communities. World Resource Institute reported that $45 \%$ of coral reefs in Indonesia face a high level of threat, and this ecosystem can still be aided by the presence of artificial reefs. This study focuses to understand the feasibility of implementing artificial reef to boost local community and boost their economy in order to preserve the environment for sustainability.
\end{abstract}

Keywords - Artificial Reef; Ecotourism; Marketing; Sustainability

\section{INTRODUCTION}

Scuba (Self-Contained Underwater Breathing Apparatus) diving as one of the fastest growing markets in the tourism industry is flourishing and widely acknowledged by many countries. Coral reefs and the aquaculture are the major magnetism to Scuba divers. As a consequence, many countries are establishing themselves as new international diving destinations [1]. Scuba diving is not only an ordinary sport. It can also impact the environment, empower the local island community which can benefit to a sustainable business.

According to Figure 1 it can be seen that the trend of scuba diving has been increasing from the 1970s to 2000s. This indicates that the scuba diving industry has successfully attracted its niche market through generations. Previous study by Windsor [2] in the year of 1994 the diving industry generated annual revenue in excess of AUD\$103 million. PADI as one of the Scuba Diving certification provider mentions that Indonesia has more than 3.500 marine species live in Indonesian waters - from pygmy seahorses and schooling hammerhead sharks to manta rays, sunfish, octopus, moray eels, cuttlefish, turtles, sharks, jackfish, dolphins, emperor angelfish, groupers, goatfish, sweetlips, frogfish, pipefish, lionfish, scorpion fish and leaf fish abound. Invertebrates also flourish here as well as sea fans, sponges, soft corals, feather stars, hard corals, hydroids, whip corals and colorful nudibranchs [3]. Indonesia as a coastal country can utilize these resources to attract global visitors to dive in Indonesia and gain the opportunity.
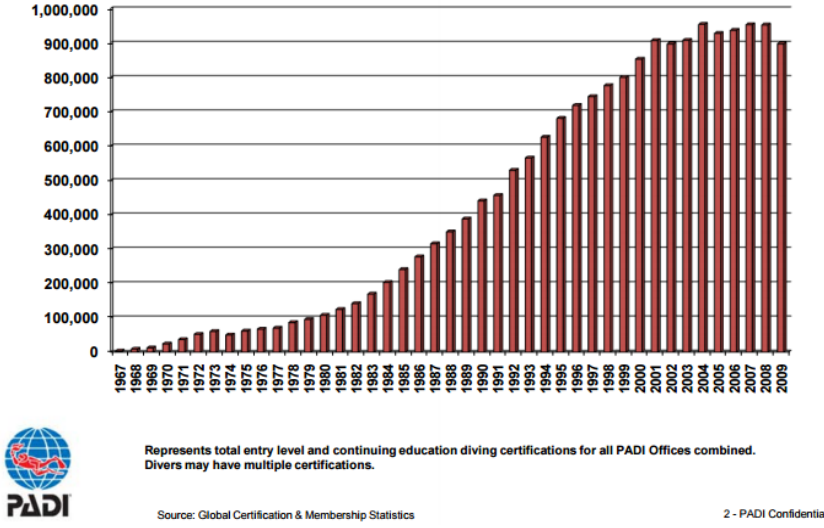

Fig. 1. Number of Certifications of PADI from 1967 - 2009

In Indonesia there are several dive spots which are popular worldwide such as in Bali, Komodo Island, Mahengetang, and Raja Ampat [4]. Amongst these internationally recognized dive sites, there are also several sites of which are not mentioned for example Bunaken Island, Lembeh Strait, Wakatobi, Sumbawa, Flores, Alor [5]. However, these islands are located in the east part of Indonesia, which is relatively distant from the capital city of Indonesia. The Seribu Islands essentially has many opportunities to gain competitive advantage due to its relatively close distance to the central of Indonesia's government and business, Jakarta.

\section{LITERATURE REVIEW}

Many studies have documented diver impacts with levels of damage to reefs often linked to intensity of use by divers and to a lack of diving experience. Previous studies reported mechanical damage in the underwater ecosystem [1]. While scuba diving as one of an ecotourism activity can help to boost the local economies and help preserve the ecosystem, there is evidence that even relatively few visitors can degrade the coral reefs provide a diverse and stimulating setting for recreational diving, as well as other marine based activities that has attracted them [6]. Some definitions of artificial reefs were made. "An artificial reef is a submerged structure placed on the substratum deliberately, to mimic some characteristics of a natural reef" [2]. Hynes et al [2] defines artificial reefs as anything placed on the near-shore sea bottom out to a depth of about 200 meters whose purpose is to stimulate fish production 


\section{Asunese PRESS}

or (at near-shore depths) serve as an attraction to divers". Another definition which is contextual to this study is from Seaman and Jensen [2] defines an artificial reef as one or more objects of natural or human origin deployed purposefully on the seafloor to influence physical, biological or socioeconomic processes related to living marine resources, defined physically by the design and arrangement of materials used in construction and functionally according to their purpose. Artificial reefs which provide objects underwater and can generate centralized ecological process can gain attention from the tourist as recreational object and can provide unique experiences for tourists. This method can give insights to humans to value the natural environments and also cultural heritage. There are some 'favorite objects' of artificial reefs where divers can experience a distinctive combination of social and natural history.

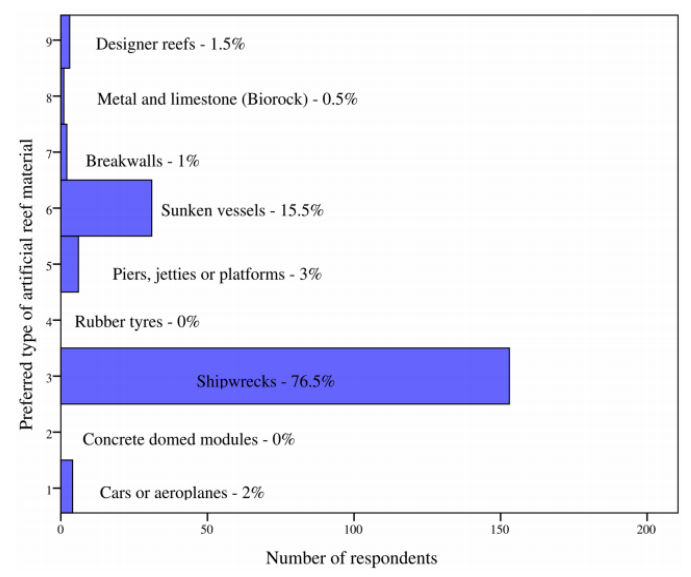

Fig. 2. Preferences for Type of Artificial Reefs Material [1]

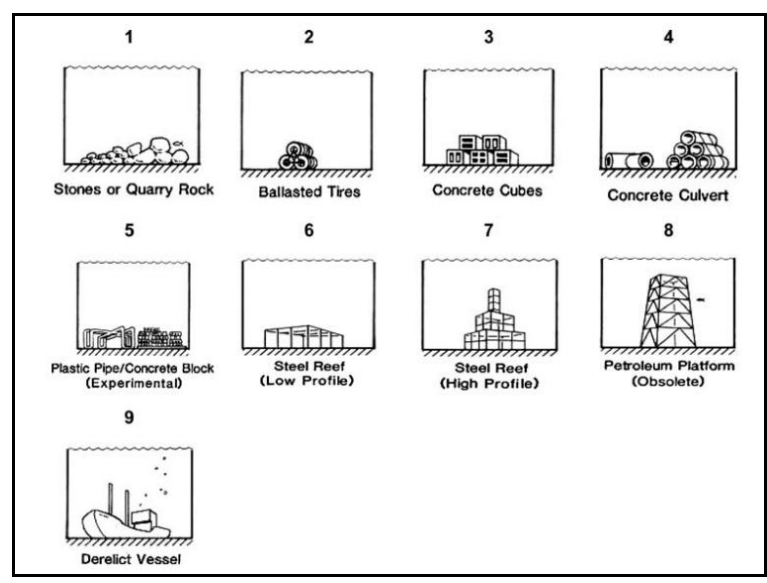

Fig. 3. Materials Commonly used for Artificial Reefs [2]

As shown on Figure 2, shipwrecks and sunken vessels are two examples of most favorited artificial reefs according to the previous studies by Smith, Wheeler \& Johnson. The sample was undertaken to 200 respondents from novice ( $<100$ dives) to experts ( $>100$ dives) in Caribbean Island of Barbados. There are several types of materials commonly used for creating artificial reefs as shown in Figure 3 such as stones or quarry rock, ballasted tires, concrete cubes, concrete culvert, steel reef, petroleum platform, derelict vessel. Based on the previous study by Arena [7] it is known that artificial reefs can generate a wide variety and large numbers of fishes. The potential risk for this is this centralized ecological substances are susceptible to fishing. This will cause conflict between fishers and tourists. Hence, protection is needed to ensure preservation and sustainability both for fishers and tourists.

There are also other types of designed-material that offers aesthetical values such as the ones that are created by Jason deCaires Taylor as shown on Figure 4. These sculptures can gain more attention from divers and also can empower the local community to develop a sustainable environment. In this study, the artificial reefs focus on the objects which can provide sustainable and environmental preservation value to the divers.

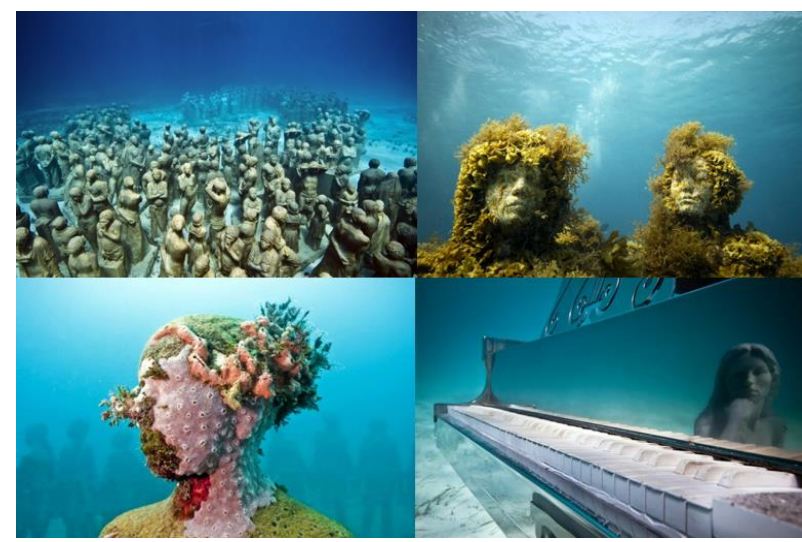

Fig. 4. Artificial Reef Sculptures [16]

Previous studies have shown that artificial reefs can attract divers due to its unique experiences gained. Divers expressed a clear preference for large shipwrecks or sunken vessels that provided a themed diving experience. Motives for diving on artificial reefs were varied, but were dominated by the chance of viewing concentrated marine life, increased photographic opportunities, and the guarantee of a 'good dive' [1]. Referring to the previous study conducted by Polak and Shashar [8], divers were willing to pay the highest sums for conservation efforts that protected high biodiversity. It means that divers understood without being told, that higher biodiversity have significant implications to the ecosystem, and they are willing to pay more for this conservation efforts [8]. Scientifically, artificial reefs are not the perfect substitutes compared to natural coral reefs. However, divers value these artificial reefs especially distinctive and unique structures which can generate and concentrate rich underwater ecosystem conditions that can provide decent quality of diving experience [1]. Artificial reefs have been shown to contribute substantially to local host economies. In view of the fact that some scuba divers place little importance on the ecological characteristics of a reef site it may be possible to satisfy divers' requirements with wellconceived artificial reef diving attractions [1]. Study by Stolk, Markwell \& Jenkins [2] mention that artificial reefs are a form of 'modified space' capable of supporting wildlife populations commonly thought to reside only in unmodified or 'natural' settings. Artificial reefs aggregate fish and other mobile marine organisms very quickly after deployment and, given time, also host fixed life forms such as algae, barnacles, mussels, sponges and soft and hard corals. In fact, some 'established' artificial 
reefs have demonstrated an ability to sustain a greater density and/or variety of biota - particularly fish species - than nearby natural reefs [2].

In order to develop sustainable and environmental protection, sustainable tourism model traits adapted Damanik and Weber [9] is used in this study which have the following characteristics:

- Reducing the negative impact of such damage or pollution of the environment and local culture as a result of tourism activities.

- Build awareness and appreciation for the environment and culture in tourist destinations, both for tourists, and local communities.

- Offers direct positive experiences for both tourists and local communities through more intensive cultural contacts and cooperation in conservation effort.

- Provide direct financial benefits for conservation purposes through contributions or extra spending tourists.

- Increased sensitivity to the social, environmental and political in tourist destinations.

- Provide financial benefits and empowerment for local communities by creating tourism products that promote local values.

- Respect for human rights and labor agreements, in the sense of giving freedom to the tourists and local people.

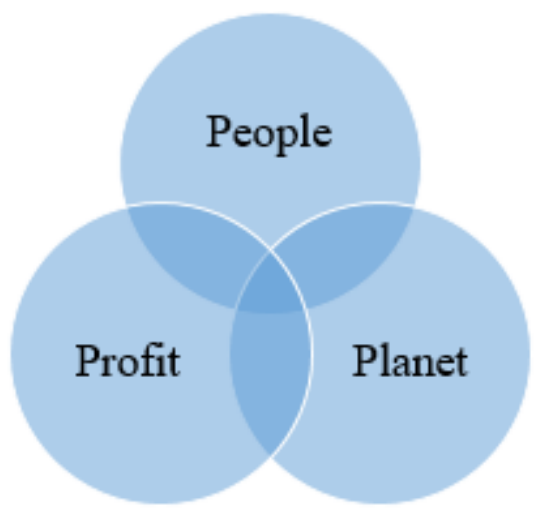

Fig. 5. Sustainability Triple Bottom Line

The author argues that Pramuka Island has not yet optimized and contributed maximum effort to natural conservation, which is in line with the study from Oceanography ITB [10]. Hence, with the implementation of artificial reefs to the Pramuka Island area, it is expected that it can contribute to the sustainability of the ecosystem and boost the economic condition of the local community. The author argues that due to the lack of studies and preservations effort from the government, these potential islands are lacking of attentions from the visitors. Even though, this opportunity shall be managed properly to build sustainable eco-tourism and attract more divers and certainly can empower the local community in these islands. This argument is supported by Stolk, et al. [2] regarding the potential advantages of implementing artificial reefs to attract Scuba divers. Hence, understanding that artificial reef is one of the method to assist the environment in managing the scuba diving impact [1], this study will discuss the feasibility of artificial reefs implementation and its effect to the local environment of Pramuka Island to promote the triple bottom line of the sustainability concept: people, planet, profit as shown in Figure 5 .

\section{METHODS}

Based on the previous studies, there are some aspects need to be analyzed for implementing artificial reefs. According to $\mathrm{Ng}$, et al. [11] there are four aspects which need to be discussed which are marine ecology and environment, socio-cultural and economics, planning, legal and construction. Conceptual model developed by Stolk et al. defines that there are contributing factors to the success of implementing artificial reefs such as artificial reef characteristics, scuba diver characteristics, and tourism and government characteristics [2]. In this study, the author specifies the scope of the research into four aspects which are the technology, legal, local community capability, and divers' opinion as the primary target. These observations will be done through qualitative triangulation of literature review, direct observation and interview.

The author divides technological capability to two aspects which are from the capability of the community to develop and maintain the artificial reefs, and the capability of scuba diving providers to run the operational business smoothly. Primary observations and discussions to the local community is expected to gain insights whether they are able or not to implement artificial reefs in this area, while scuba diving services provider' opinions regarding their operational capability to conduct the business are also taken into account to ensure that the business operations can run decently in the future. The observation is conducted from September 2015 to March 2016. Secondary data is used to assess the technological and environmental aspects, while social and economic is done through primary observation in Pramuka Island. Figure 5 shows the satellite imagery of Pramuka Island. Pramuka Island is located on the northern part of Jakarta and administratively, Pramuka Island is located in the District of Seribu Islands. The geographical location of the Scout Island is $5^{\circ} 44^{\prime} 19^{\prime \prime}-5^{\circ} 45^{\prime} 05^{\prime \prime}$ latitude and $106^{\circ} 36^{\prime} 35-106^{\circ} 37^{\prime} 07^{\prime \prime}$ longitude. Table 1 shows the water quality of Pramuka Island.

TABLE I. WATER Quality of PramuKa IsLAND [10]

\begin{tabular}{|l|l|l|}
\hline \multicolumn{1}{|c|}{ Parameter } & \multicolumn{1}{c|}{ Observation Result } & \multicolumn{1}{c|}{ Remarks } \\
\hline $\mathrm{pH}$ & $7.2-7.4$ & Normal \\
\hline Salinity & $25-28 \mathrm{psu}$ & Normal \\
\hline Temperature & $29-30^{\circ} \mathrm{C}$ & Normal \\
\hline
\end{tabular}

There are total seven respondents in this study with various logged dive under CMAS or PADI certification. Certification levels ranging from A1 to B2. Scuba Divers interviewed on this study have been diving in Pramuka Island for at least three 
times. These experiences are sufficient to give general feedback analysis regarding the condition of Pramuka Island.

TABLE II. RESPONDENTS PROFILE

\begin{tabular}{|c|c|l|}
\hline Respondents & $\begin{array}{l}\text { Total Dives in } \\
\text { Pramuka Island }\end{array}$ & \multicolumn{1}{|c|}{ Certification } \\
\hline 1 & 11 & $\begin{array}{l}\text { CMAS, PADI, SSI, } \\
\text { POSSI }\end{array}$ \\
\hline 2 & 15 & $\begin{array}{l}\text { CMAS, PADI, SSI. } \\
\text { POSSI }\end{array}$ \\
\hline 3 & 6 & CMAS, POSSI \\
\hline 4 & 9 & CMAS, POSSI \\
\hline 5 & 4 & CMAS, POSSI \\
\hline 6 & 3 & CMAS, POSSI \\
\hline 7 & 3 & CMAS, POSSI \\
\hline
\end{tabular}

The interview is conducted to observe their willingness to spend more money in the purpose of environment preserving while Scuba diving in Pramuka Island. Feedback and arguments are also taken into account to broaden the perspective in analyzing the potential to enhance the marketing strategy.

\section{RESUlt AND DisCUSSION}

According to the interview and discussions to the respondents it is found that most respondents are willing to pay more for environmental conservation efforts. All respondents showed positive feedback on the concerns of environment and local community empowerment. They are willing to pay by 100.000 rupiahs at the highest for a jar sized artificial reef to be planted in the sea ecosystem when they dive. These certified divers have shown concerns not just for the environment but for the community.

Technological capability is analyzed to the Pramuka Island of which several issues are discussed to determine the feasibility of implementing artificial reefs. Numerous techniques as discussed in previous chapter in planting artificial reefs are shown to the local community to discuss which structures are more feasible and also preferable to be planted. It is found that the soft coral of which a coral planted on a block of cement is one that are feasible to be done by the locals, while other type of artificial reefs that can be planted under the surface by the diver also possible. However, underwater sculpture is also feasible with further empowerment of the locals by experienced sculptor. This will also enhance the local community by creating sculptures for centralized ecosystem with aesthetical value. In terms of scuba diving as recreational activity, Pramuka Island has a number of dive shops to support basic sufficient resources to satisfy the primary needs of scuba divers. This is shown by the presence of several dive shops such as Mazu Divers and Ody Dive Center. Ody Dive Center, for example, provides air filling station with two large sized compressors, 60 Genesis Tanks, Sherwood Diving gear, Tilos Snorkeling gear, PADI Dive Master. There are also local dive shops spanning in Jakarta areas such as Bubbles Dive Center that can facilitate Scuba divers to dive in the Pramuka Island.

Direct observations to the Pramuka Island resulted that the local community is actually aware on developing basic artificial reefs. The local community also showed awareness when discussing the environment preservation with artificial reefs. This is shown by several projects of planting artificial reefs in Pramuka Island. They also understand the importance of environmental preservation and local community empowerment. Panggang Island which is near the Pramuka Island also have applied this basic technique to preserve the environment. In Panggang Island, tourists are invited to buy for sea horses cultivation that are ready to be released into the sea, and mini coral that can be planted underwater. In Tulamben, Bali, it can be seen that artificial reefs based on the sculptures, statues do exist and it attract divers to come to Bali. Meanwhile, the aspect of legal is also observed and discussed in this study. These aspects are analyzed to collect information regarding the regulations to implement artificial reefs. According to the observation to the local communities, it is found that artificial reefs have been implemented in a nonroutine basis. The regulations that support this activity is found on the Decree of the Minister of Maritime and Fisheries Affairs no. 38/2004 regarding the general guidance of coral reefs preservation. With a structured and well-formalized business model, this will support the legal aspects and regulation set by the government of Indonesia.

In view of the technological aspects, through direct observations and interviews it is shown that applying artificial reefs as a recreational scuba diving resources is feasible to be implemented. This is supported both by the scuba business providers in Jakarta area as well as in the Pramuka Island. Elementary requirements for scuba diving has been provided, also mode of transports from Jakarta to Pramuka Island and vice versa is ready. Meanwhile, boat to explore the area of Pramuka Island is also present. Hence, in terms of technological aspect, it can be concluded that it is feasible to deliver this innovation. Capability of the locals to create this artificial reefs are also taken into account. As the people of Panggang Island can develop artificial reef, Pramuka Island local communities can also benchmark and apply this idea with additional innovation from the experts. Several techniques such as sculptures, installed under water cement blocks, and other technologies may need more study whether it is feasible to be planted underwater. Pramuka Island on this study is believed to be have the potential to provide this business strategy in order to preserve the environment and boost the local economy. Several types of artificial reefs can be applied such as shown in Figure 7, planting the transplanted coral to the cemented blocks underwater.

Other types of artificial reefs are also possible, for example as shown in Figure 6. It can be seen that the sculptures of Buddha in Pemuteran, Bali, is also feasible to be implemented. The locals can provide this sculptures by cooperation with the government, private or freelance sculptors, or even invite sculpting instructors. Divers have also showed responsibility, concerns and willingness to spend extra efforts and money. Positive feedback from the respondents are the indicators that they recognize the importance of environmental conservation and also for the development of local communities. The local community can actually raise the awareness to the visitors, divers, and also to fishermen near the Island to collaborate together. Economically, according to previous studies this 


\section{Asuneses PRESS}

enhancement will benefit the local communities in the long term, which is in line with the sustainability on the local community concept in this study. In terms of legal aspects, this activity is clearly considered as legal and support the national regulation.

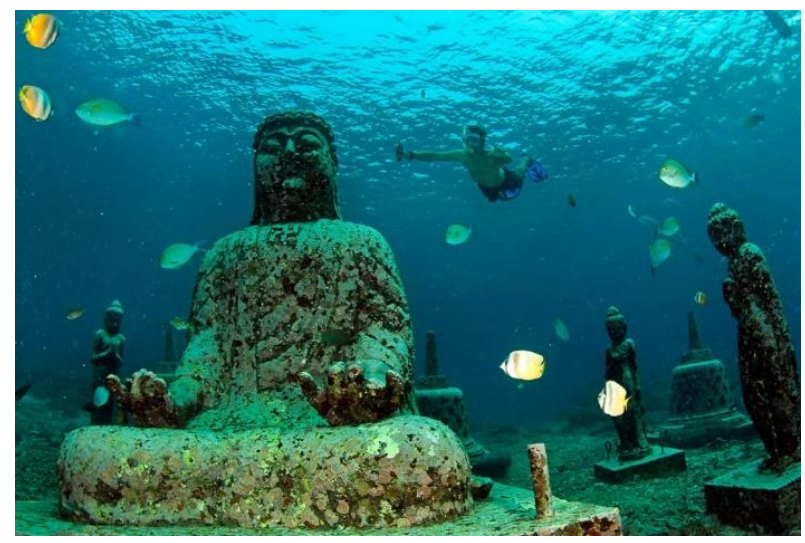

Fig. 6. Planting Artificial Coral on Cemented Blocks Underwater [12]

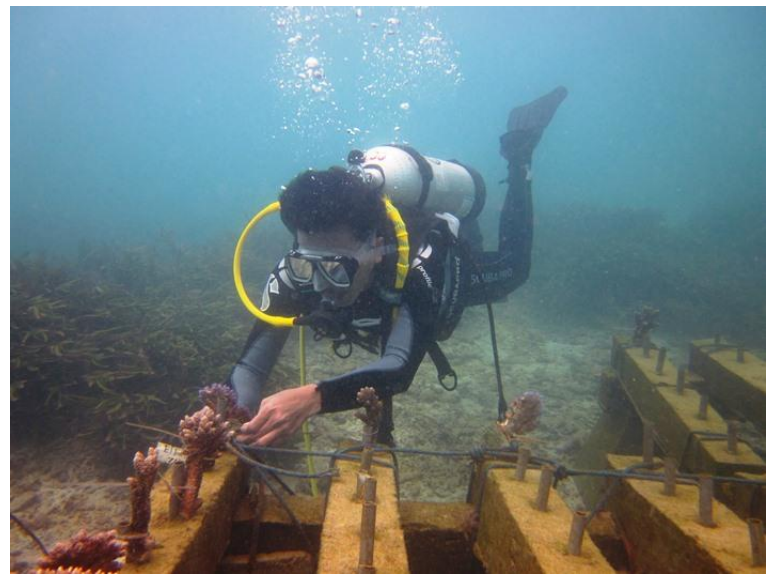

Fig. 7. Sculptures that Build Centralized Ecosystem at Pemuteran, Bali [13]

\section{CONCLUSION}

According to these study, it can be concluded that the implementation of artificial reef on Pramuka Island as scuba diving recreational activity is still considered feasible, legal and will support the regulations in preserving the environment and also to boost local community. However, collaboration between all aspects in marketing artificial reefs as recreational resources in scuba diving for long term sustainability is compulsory. In the long term, sustainable tourism in this study is focused to support the environment, boost the economic condition of local communities, and therefore create a sustainability. In this study, it is expected that the government can support the investment of this project since this will also impact the GDP of Indonesia through tourism. This research contributes to the sustainability of the local community in Pramuka Island.

However, improvements are necessary for serving better quality in delivering the scuba diving services. Compared to the dive shops the author observed in Gili Trawangan, Lombok on 2015, Pramuka Island is essentially suggested for improvements in the tangible aspects and reliability of the staffs. This study only limits the scope to the Pramuka Island and only in four aspects. There may be some aspects that need further study which is not discussed in this paper. Upon this study, trial implementation and evaluation is needed to continuously monitor the business operations and test the marketability of marketing the artificial reefs

\section{BIBLIOGRAPHY}

[1] A. Kirkbride-Smith, P. Wheeler and M. Johnson, "The Relationship between Diver Experience Levels and Perceptions of Attractiveness of Artificial Reefs - Examination of a Potential Management Tool," PLoS ONE, 2013

[2] P. Stolk, K. Markwell and J. Jenkins, "Artificial Reefs as Recreationa Scuba Diving Resources: A Critical Review of Research," Journal of Sustainable Tourism, 2007.

[3] "Dive Indonesia | Padi," $14 \quad 3$ 2016. [Online]. Available: https://www.padi.com/scuba-diving/scuba-diving-travel/vacationspotlights/indonesia/.

[4] J. Bremner, "Into the Deep: World's 50 Best Dive Sites |CNN Travel," 6 April 2012. [Online]. Available: http://travel.cnn.com/explorations/escape/outdoor-adventures/worlds-50 best-dive-sites-895793/.

[5] "Indonesia Scuba Diving," 2016. [Online]. Available: http://www.divetheworldindonesia.com/.

[6] J. Hawkins, D. Kooistra, C. Roberts, K. Buchan and S. \& White, "Sustainability of Scuba Diving Tourism on Coral Reefs of Saba.," Coastal Management, pp. 373-387

[7] P. Arena, "Protecting Fish Assemblages on Sunken Vessels to Enhance Diving Ecotourism and Local Natural Resources," Journal of Coastal Research, pp. 375-377, 2011.

[8] A. Shani, O. Polak and N. Shashar, "Artificial Reefs and Mass Marine Ecotourism," Tourism Geographies, pp. 361-382, 2012.

[9] J. Damanik and H. F. Weber, Perencanaan Ekowisata Dari Teori ke Aplikasi, Yogyakarta: Andi Offset, 2006.

[10] Topan Eko Raharjo, et.al., "Laporan Ekskursi Pulau Pramuka," 2012. [Online]. Available: http://blogs.itb.ac.id/topan/files/2012/05/LAPORAN-EKSKURSIKELOMPOK-7.pdf

[11] K. Ng, T. Thomas, M. Phillips, H. Calado, P. Borges and F. VelosoGomes, "Multifunctional Artificial Reefs for Small Islands: An Evaluation of Amenity and Opportunity for Sao Miguel Island, the azores," Progress in Physical Geography, vol. 39, no. 2, pp. 220-257, 2015

[12] P. R. Hernasari, "Melihat Budidaya Terumbu Karang," 15 May 2012. [Online].

Available: http://travel.detik.com/read/2012/05/15/085100/1917137/1025/1/melihat -budidaya-terumbu-karang\#menu_stop.

[13] Be My Guest, "Be My Guest Travel Blog," 2016. [Online]. Available: https://blog.bemyguest.com.sg/bali-beyond-mainstream/.

[14] A. Haryanto, "Efektifitas Rehabilitasi Mangrove Di Pulau Pramuka Kepulauan Seribu," 2013.

[15] V. T. Middleton and R. Hawkins, Sustainable Tourism: A Marketing Perspective, Eastbourne: Antony Rowe Ltd, 1998.

[16] C. Jobson, "Collosal," 27 June 2012. [Online]. Available: http://www.thisiscolossal.com/2012/06/human-nature-jason-decairestaylors-submerged-figurative-sculptures-form-thriving-artificial-reefs/.

[17] Marine Bio, "Sustainable Ecotourism," 2016. [Online]. Available: http://marinebio.org/oceans/conservation/sustainable-tourism/.

[18] L. G. Son, C. S. Beng, U. Skulkerewathana and R. Daft, New Era of Management in a Globalized World: An Asian Perspective, Singapore: Cengage Learning Asia Pte Ltd, 2015

[19] World Economic Forum, "The Travel \& Tourism Competitivenes Report 2015: Growth through Shocks," 2015 